\title{
Immunosuppressive Treatment in Children with Acquired Aplastic Anemia
}

\author{
Edinsel Aplastik Anemili Çocuklarda İmmünsüpresif Tedavi
}

\author{
Yıldız Yıldırmak, Ela Erdem, Leyla Telhan, Laliz Kepekçi \\ Sisli Etfal Training and Research Hospital, Department of Pediatrics, İstanbul, Turkey
}

\begin{abstract}
Objective: Immunosuppressive treatment (IST) is an alternative for children with acquired aplastic anemia (AA) that do not have HLA-matched donors. The objective of this study was to evaluate the outcome of IST in children with acquired AA.
\end{abstract}

Material and Methods: The study included 18 pediatric acquired AA patients that were retrospectively evaluated. The patients either did not have an HLA-matched related donor or were unable to undergo transplantation within 6 months despite having an HLA-matched donor.

Results: In all, 6 of the patients were characterized as very severe AA, 6 as severe AA, and 6 as moderate AA. Mean duration of follow-up was $\mathbf{4 4 . 5}$ months. In total, 9 patients that could not be treated with equine anti-thymocyte globulin (hATG) following diagnosis received high-dose methylprednisolone treatment. Among the 6 very severe AA patients, 2 achieved complete remission (22\%); the other 16 patients received hATG+cyclosporine and short-term methylprednisolone.

In total, 4 of the patients died during the first month of treatment. Of the remaining 12 patients, 3 responded to the treatment (25\%). Of the 9 patients that did not respond after 3 months of treatment, 7 received a second course of immunosuppressive treatment with rabbit ATG (rATG)+cyclosporine and short-term methylprednisolone; 2 of the 7 patients responded (22\%), but 5 did not respond to any treatment. Median survival among the patients was as $64 \pm 8$ months

Conclusion: Combination IST with ATG+cyclosporine and low-dose methylprednisolone was an effective treatment in the pediatric acquired AA patients with non-identical HLA donors. In the patients that couldn't be treated with ATG high-dose methylprednisolone treatment was safe and effective.

Key Words: Immunosuppressive treatment, Acquired aplastic anemia, Children

Özet

Amaç: İmmunsupresif tedavi (IST), HLA uyumlu vericisi olmayan edinsel aplastik anemili (AA) çocuklarda diğer bir tedavi seçeneğidir. Bu çalışmada edinsel AA’li çocuklarda İST sonuçlarının değerlendirilmesi amaçlanmıştır.

Gereç ve Yöntemler: Çalışmada 18 edinsel AA'li çocuk hasta retrospektif olarak incelendi. Tanı sırasında HLA uygun akraba içi vericisi olmayan ya da HLA uygun vericisi olmasına rağmen 6 ay içinde nakil olamayacak hastalar çalışmaya alındı.

Address for Correspondence: Yıldız YILDIRMAK, M.D.,

Şişli Etfal Eğitim ve Araştırma Hastanesi, Çocuk Sağlığı ve Hastalıkları Anabilim Dalı, İstanbul, Turkey

Phone: +90 2122196750 E-mail: yyildirmak@yahoo.com

Received/Gelis tarihi : July 12, 2010

Accepted/Kabul tarihi : March 5, 2011 
Bulgular: Hastaların 6'sı çok ağır AA, 6'sı ağır AA ve 6'sı da orta AA sınıfında idi. Ortalama takip süresi 44.5 ay bulundu. Tanı konulduktan sonra at kaynaklı anti-timosit globulin (hATG) temin edilemeyen 9 hastaya yüksek doz metilprednizolon tedavisi verildi. Çok ağır AA'li 6 hastanın 2'sinde (\%22) tam remisyon elde edildi. Geri kalan 16 hastaya hATG+siklosporin ve kısa süreli metilprednizolon tedavisi verildi.

Tedavi uygulamasını takiben bir ay içinde dört hasta kaybedildi. Geriye kalan 12 hastanın 3’ü (\%25) tedaviye cevap verdi. Tedaviye başladıktan 3 ayın sonunda cevap alınamayan 9 hastanın 7'sine tavşan kaynaklı ATG (rATG)+siklosporin ve kısa süreli metilprednizolon ile ikinci kür İST verildi. Bu 7 hastanın 2'sinde (22\%) cevap alındı, ancak 5 hasta tedaviye cevap vermedi. Ortalama yaşam süresi $64 \pm 8$ ay bulundu.

Sonuç: ATG+siklosporin ve düşük doz metilprednizolon ile kombinasyon İST, HLA uygun vericisi olmayan edinsel AA'li çocuk hastalarda etkin bir tedavidir. ATG ile tedavi edilemeyen hastalarda yüksek doz metilprednizolon tedavisi güvenli ve etkilidir.

\section{Anahtar Sözcükler: İmmunsupresif tedavi, Edinsel aplastik anemi, Çocuklar}

\section{Introduction}

The primary treatment for acquired aplastic anemia (AA) is hematopoietic stem cell transplantation (HSCT) from HLA-matched sibling donors. The procedure has a survival rate of up to $88 \%$ to $97 \%$ [1]. Immunosuppressive therapy (IST) is an alternative to HSCT, especially in patients without an HLA-matched donor [1,2]. There are limited data available on the use of IST in pediatric patients; however, a large series of patients aged 1-50 years was analyzed by the European Group for Blood and Marrow Transplantation (EBMT), which concluded that HSCT should be the first-line treatment, especially in patients aged $<10$ years, those with severe $\mathrm{AA}$, and those with an HLA-matched sibling donor $[1,2]$.

Current IST options include single-dose anti-thymocyte globulin (ATG), single-dose cyclosporine (CsA), ATG+anti-lymphocyte globulin (ALG), androgens, corticosteroids, high-dose cyclophosphamide, and mycophenolate mofetil [3-5]. Moreover, the ATG+ALG combination is currently the most widely used regimen, although highdose cyclophosphamide therapy has been also reported [6]. The response rate to the combination of ATG+CsA is approximately $75 \%$ [7]. The aim of the present study was to evaluate the outcome of IST in pediatric acquired AA patients that could not undergo HSCT.

\section{Materials and Methods}

\section{Inclusion criteria}

Patients that presented to Sisli Etfal Training and Research Hospital, Pediatric Hematology Department between 2000 and 2008 with the diagnosis of AA were analyzed retrospectively. None of the patients had a history of using medications that can cause AA and none had hepatitis or immune-mediated disorders. All the patients included in the study had negative diepoxybutane chromosome fragility findings. Patients diagnosed as hereditary AA or those that had HLA-matched donors and underwent HSCT were excluded from the study.

\section{Disease classification}

AA was classified according to severity. AA was classified as severe on the basis of bone marrow cellularity $<25 \%$ and the presence of $\geq 2$ of the following criteria: neutrophil count $<0.5 \times 10^{9} / \mathrm{L}$, platelet count $<20 \times 10^{9} / \mathrm{L}$, and reticulocyte count $<20 \times 10^{9} / \mathrm{L}$. In addition to the above mentioned criteria, AA was classified as very severe if the neutrophil count was $<0.2 \times 10^{9} / \mathrm{L}$. AA was classified as moderate in the presence of hypocellular bone marrow and any 2 of the following criteria: neutrophil count $<1.0$ $\times 10^{9} / \mathrm{L}$, platelet count $<50 \times 10^{9} / \mathrm{L}$, and reticulocyte count $<60 \times 10^{9} / \mathrm{L}[3,4]$.

Following diagnosis, if ATG could not be administered, high-dose methylprednisolone (HDMP) treatment was given. HDMP treatment was administered as $30 \mathrm{mg} / \mathrm{kg}$ for 3 days, and then $20 \mathrm{mg} / \mathrm{kg}$ for 4 days; after the lst week of treatment the dose was decreased to $10 \mathrm{mg} / \mathrm{kg} /$ day for the $2 \mathrm{nd}$ week, $5 \mathrm{mg} / \mathrm{kg} /$ day for the $3 \mathrm{rd}$ week, and $2 \mathrm{mg} / \mathrm{kg} /$ day for the 4th week, after which time the treatment was withdrawn [8]. Patients received ATG if it was provided immediately after the diagnosis or if they did not respond to HDMP treatment (at least 1 month later after the beginning of HDMP treatment). The equine ATG (hATG) regimen was as follows: hATG $15 \mathrm{mg} / \mathrm{kg}$ for 5 days, CsA $5 \mathrm{mg} /$ $\mathrm{kg} /$ day for 60 days, and prednisolone $2 \mathrm{mg} / \mathrm{kg} /$ day for 10 days. Prednisolone dose was tapered to end on day 30. Patients that did not respond to hATG after 3 months of treatment, received ATG of rabbit origin (rATG) at a dose of $3.75 \mathrm{mg} / \mathrm{kg} /$ day for 5 days and CsA was continued at 
the same dosage. Prednisolone was also used at the same dosage with hATG regimen $[4,9]$.

Platelets were transfused when the platelet count was $<20 \times 10^{9} / \mathrm{L}$ or when there was bleeding; erythrocyte suspension was given when the hemoglobin level was $<7 \mathrm{~g} / \mathrm{dL}$ and there was symptomatic anemia.

\section{Response criteria}

Total response was defined as hemoglobin within agedefined normal limits, a platelet count $>100 \times 10^{9} / \mathrm{L}$, and a neutrophil count $>1.5 \times 10^{\%} / \mathrm{L}$. Partial response was defined as a reticulocyte count $>30 \times 10^{9} / \mathrm{L}$ (independent of transfusion), a platelet count $>30 \times 10^{9} / \mathrm{L}$, and a neutrophil count $>0.5 \times 10^{9} / \mathrm{L}$ [10]. In patients that responded to treatment, the time required for partial and complete response was analyzed. The period from diagnosis to initiation of treatment was compared between the patients that did and did not respond to the treatment. All patients underwent bone marrow aspiration at 6 and 12 months, and then yearly after the diagnosis, so that they were evaluated for myelodysplasia, which was defined as the appearance of a new clonal disorder observed cytogenetically or characteristic morphologic changes in bone marrow examination findings.

Statistical analysis was performed using SPSS v.11.0 (Chicago, IL, U.S.A.) Descriptive statistics, including mean, median, and standard deviation, were calculated for all variables. The Mann-Whitney $U$ test was used to compare scale variables and the survival rate was assessed via the Kaplan-Meier method.

\section{Results}

The study included 18 children that underwent IST at our hospital between 2000 and 2008. Patient demographic data are shown in Table 1.

\section{Response to IST}

After the diagnosis of AA, ATG could not be given to 9 patients; instead they were given HDMP treatment. Complete response was achieved in only 2 of these 9 cases (22\%), both of which had very severe AA. In total, 7 of the patients that did not respond to HDMP and 9 of patients who provided hATG received hATG, CsA, and prednisolone treatment. In all, 4 of these 16 patients died during the first month of treatment. The causes of death were infection in two patients (mucormycosis and septicemia), bleeding in one patient and ensephalopathy in the other. Of the 12 patients that survived, 3 (25\%) responded to treatment, of whom 2 had moderate AA and 1 with very severe AA. In these patients who responded, CsA was stopped after tapering in 3 months.
Table 1: Patient demographics.

\section{Patient characteristics}

$\mathrm{n}: 18$

\begin{tabular}{l|c} 
Male:female ratio & $11: 7$ \\
Mean age at the time of diagnosis (years) & 7.9 \\
Median age at the time of diagnosis (years) & 8 \\
Disease severity at the time of diagnosis & \\
$\quad$ Very severe & 6 \\
$\quad$ Severe & 6 \\
$\quad$ Moderate & 6 \\
Patients that received HDMP & 9 \\
Patients that responded to treatment & 2 \\
Number of immunotherapy courses & \\
1 (hATG) & 12 \\
2 (hATG and rATG) & 7 \\
Treatment response (to hATG and rATG) & \\
Total response & 5 \\
Partial response & - \\
No response & 7 \\
Early Exitus & 4 \\
Result & \\
Alive without transfusion & 7 \\
Alive and dependent on transfusion & 4 \\
Early exitus & 4 \\
Exitus after the first course & 2 \\
Exitus after the second course & 1 \\
&
\end{tabular}

In total, 9 patients did not respond to 3 months of treatment; 7 subsequently received a second course of IST consisting of rATG. Prednisolone treatment was repeated and the patients received CsA treatment as the same dosage for six months. Two of the unresponsive patients chose not to receive a second course of IST; they died after 6 and 15 months of follow-up due to bleeding and infection, respectively. Among the 7 patients that underwent the second course of IST, 2 had complete response (22\%) (1 with moderate $\mathrm{AA}$ and 1 with severe $\mathrm{AA}$ ) and the other 5 did not respond to the second course of treatment (2 with moderate AA, 2 with severe AA, and 1 with very severe AA) (Table 2). One of the unresponsive cases died due bleeding at the end of 12-months of follow-up; the other 4 cases were still being follow-up without a response at the time this report was written.

In the patients that responded to IST the time required for partial or complete response was analyzed. In the 2 patients that responded to HDMP the time for partial and complete response was $1.5 \pm 0.5$ months and $3.5 \pm 0.5$ 
Table 2: Treatment responses according to disease severity.

\begin{tabular}{|c|c|c|c|c|c|c|c|}
\hline $\begin{array}{c}\text { Severity of } \\
\text { disease }\end{array}$ & $\begin{array}{c}\text { Treatment } \\
\text { group }\end{array}$ & $\begin{array}{c}\text { Response } \\
\text { (n) }\end{array}$ & $\begin{array}{l}\text { Treatment } \\
\text { group }\end{array}$ & $\begin{array}{c}\text { Response } \\
\text { (n) }\end{array}$ & $\begin{array}{l}\text { Treatment } \\
\text { group }\end{array}$ & $\begin{array}{c}\text { Response } \\
\text { (n) }\end{array}$ & $\begin{array}{l}\text { Overall } \\
\text { response } \\
n=14^{*}\end{array}$ \\
\hline & HDMP & & $\begin{array}{l}\text { hATG }+ \text { CsA } \\
\text { (1st course) }\end{array}$ & & $\begin{array}{c}\text { rATG+CsA } \\
(2 \text { nd course) }\end{array}$ & & \\
\hline $\begin{array}{c}\text { Moderate } \\
(n=6)\end{array}$ & 3 & - & 5 & 2 & 3 & 1 & 3 \\
\hline $\begin{array}{l}\text { Severe } \\
(\mathrm{n}=6)\end{array}$ & 3 & - & 3 & - & 3 & 1 & 1 \\
\hline \multirow[t]{2}{*}{$\begin{array}{c}\text { Very severe } \\
\quad(n=6)\end{array}$} & 3 & 2 & 4 & 1 & 1 & - & 3 \\
\hline & & 2 & & 3 & & 2 & $\% 50$ \\
\hline
\end{tabular}

*The 4 patients that died during the first month of treatment were excluded.

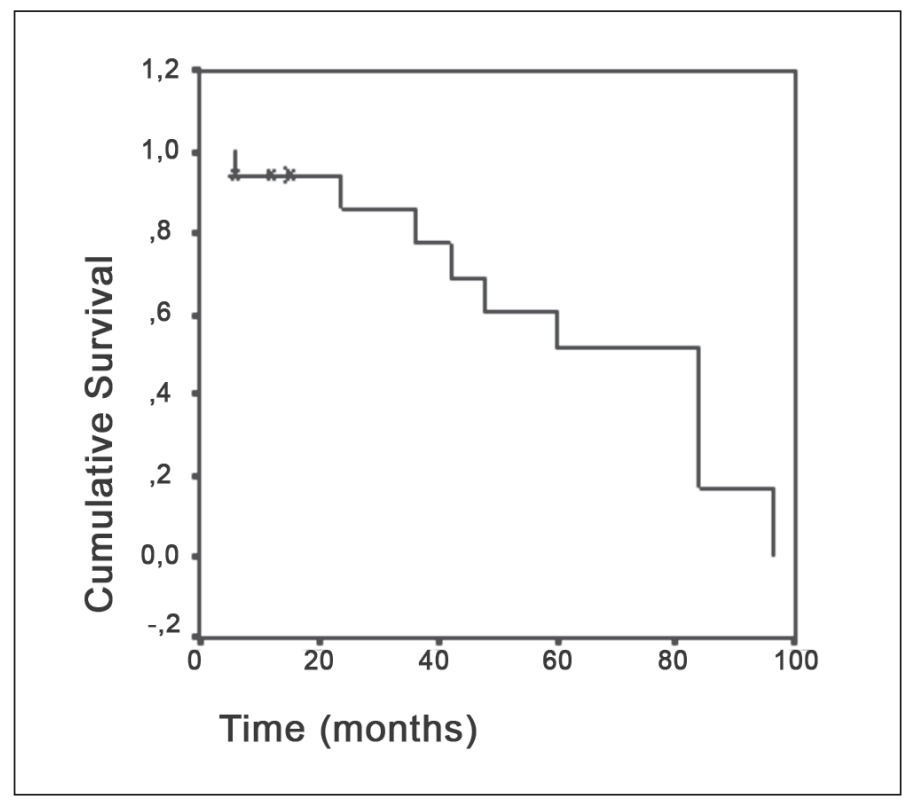

Figure 1: Cumulative survival rate in 18 children with aplastic anemia treated with immunosupressive therapy.

months, respectively. Of the 3 patients that responded to hATG, partial response was obtained in $4.5 \pm 0.5$ months and complete response in $12 \pm 1.6$ months. In the patients that received rATG as a second course following hATG, partial and complete response was achieved in $3.3 \pm 0.4$ months and $11.3 \pm 0.9$ months, respectively. Patients treated with hATG became transfusion free in a mean duration of $3.7 \pm 1.4$ months.

Mean duration of survival in the responsive and unresponsive patients was $76.8 \pm 9.8$ and months and $54.8 \pm$
17.2 months, respectively; the difference was significant ( $p=0.043$ ). The estimated survival rate was $77 \%$ in the responsive patients and the survival rate was $51 \%$ in the unresponsive patients. Mean time from diagnosis to the start of treatment was $3.8 \pm 3.8$ months (range: 1 month12 months); among the responsive and unresponsive patients, it was $2.6 \pm 2.5$ and months and $4.4 \pm 4.5$ months, respectively. Although the difference was significant, the patients that responded to treatment received began treatment sooner than those that were unresponsive.

None of the patients in the present study received Granulocyte colony-stimulating factor (G-CSF). During $44.7 \pm$ 35.2 months of follow-up none of the patients relapsed. Median duration of survival was $64 \pm 8$ months (range: 6-96 months) (Figure 1), and 5-year event-free survival was $61 \%$. None of the patients exhibited evidence of clonal evolution to MDS or AML, according to bone marrow examination findings; however, cytogenetic examination of bone marrow samples is not commonly performed at the onset of disease or in unresponsive patients because of the difficulty in obtaining a sufficient number of cells for analysis.

\section{Discussion}

During the last 2 decades the use of combination IST in children with AA has increased the treatment response rate and survival time [3]. Although the peak age for the development of aplastic anemia is 15 to 25 years or older than 60 years, it also occurs in children [1]. Mean age of the patients in the present study was $7.9 \pm 2.5$ years. Although the male:female ratio is reported to be $1: 1$, males 
predominated in the present study which was approximately 1.5:1 [1,11].

HDMP was given to 9 of our patients that could not be given ATG because of unavailability. Total response was achieved in only 2 of our patients. Patients with severe AA had higher survival rates with IST than other AA patients [10]. Recently, Huang et al. reported $73 \%$ overall response and $89.4 \%$ actuarial 5 -year survival in children with severe AA that received IST [12]. Kurre et al. reported in a review that the combination of ATG/ALG+CsA yielded a response rate of $65 \%$ in 6 months and an overall response rate of $75 \%$ [14]. Despite the fact that the patients in the present study that responded to HDMP had very severe group $\mathrm{AA}$, among those that responded to ATG and CsA, 3 had moderate AA, 1 had severe AA, and 1 had very severe AA.

Patients that do not respond to an initial course of IST may respond to a second course of a similar or different ATG product [7]. Among the 7 patients in the present study that did not respond to the lst course of treatment and received a 2 nd course, 2 achieved total response. In all, 12 patients were treated with ATG+CsA; 5 (22\%) had complete response and 7 (43\%) had no response. Mean duration from the onset of treatment to remission for complete response was $12 \pm 1.6$ months among the patients treated with hATG and $11.3 \pm 0.9$ months among those that did not respond to hATG and received rATG.

In addition to early and late side effects caused by the use of ATG, several studies reported early deaths due to infection [9]. In the present study 2 patients had early death due to infection; 1 had severe AA and 1 had very severe AA. In patients with severe AA the early death rate due to infection is reported to be higher than in other AA patients. In the present study the early infection-related mortality rate was $11.1 \%(n=2)$. Zheng reported that infection-related mortality was $17 \%$ during the first 6 months of IST including hATG, CsA and prednisolone [15]. Several studies reported a relapse rate of $36 \%$ following IST in AA patients, whereas when CsA was tapered slowly the rate dropped to $10 \%-30 \%[4,16]$. In the present study doses were tapered slowly, which may be why relapses were not observed. Relapses following IST have occurred as late as 10 years post treatment [1]. Mean duration of follow-up in the present study was $44.7 \pm 35.2$ months. We think it is important to observe patients at least 10 years inorder to access the risk of relapse.

Malignant transformation to MDS/AML is the most frequent complication of $\mathrm{AA}$ in patients with long-term survival; the cumulative risk is $15 \%$ in $7-8$ years [7]. It remains unclear if clonal disease occurs during the natural course of AA or if it is related to IST. The patients in the present study did not develop clonal disease, which may have been due to the short-term mean follow-up of $44.7 \pm 35.2$ months. Long-term use of G-CSF is known to increase the risk of MDS. Although G-CSF is safe for shortterm administration, Kojima et al. reported that addition of G-CSF to IST had no benefit, in terms of hematologic response, incidence of documented infection, or overall survival in children with AA and a neutrophil count $>0.2$ $x 10^{9} \mathrm{~L}$ [17]. A recent review reported that although G-CSF treatment minimally increases the risk of leukemia in MDS patients and those with severe AA, a causal relationship between G-CSF treatment and risk of leukemia could not be entirely excluded [18]; therefore, we did not use G-CSF in the present study, which might explain why none of the patients developed clonal disease.

In conclusion, the overall response rate to IST in children with AA in the present study is encouraging. The response rate obtained in the present study was lower than previously reported, which may have been because 2 patients refused a second course of IST. We think that if these 2 patients received a second course of IST, a higher overall response rate would have been obtained. Children with AA should receive IST as first-line treatment if they do not have an HLA-identical sibling donor. Combined IST with ATG, CsA, and low-dose methylprednisolone was an effective treatment option for our pediatric patients without an HLA-identical donor; however, in patients that cannot be given ATG HDMP treatment can be used as an alternative to IST, as it is an inexpensive and safe treatment option.

\section{Conflict of Interest Statement}

The authors of this paper have no conflicts of interest, including specific financial interests, relationships, and/ or affiliations relevant to the subject matter or materials included.

\section{References}

1. Shimamura A, Nathan DG: Acquired aplastic anemia and pure red cell aplasia. In: Orkin SH, Nathan DG, eds. Nathan and Oski's Hematology of Infancy and Childhood. 7th ed. Phiadelphia: Saunders, 2009: 276-305

2. Bacigalupo A: Treatment strategies for patients with severe aplastic anemia. Bone Marrow Transplant 2008;42 Suppl 1: $42-44$ 
3. Saracco P, Quarello P, Iori AP, Zecca M, Longoni D, Svahn J, Varotto S, Del Vecchio GC, Dufour C, Ramenghi U, Bacigalupo A, Locasciulli A: Cyclosporin A response and dependence in children with acquired aplastic anaemia: A multicentre retrospective study with long-term observation follow-up.Br J Haematol 2008; 140 (2): 197-205

4. Bacigalupo A, Bruno B, Saracco P, Di Bona E, Locasciulli A, Locatelli F, Gabbas A, Dufour C, Arcese W, Testi G, Broccia G, Carotenuto M, Coser P, Barbui T, Leoni P, Ferster A: Antilymphocyte globulin, cyclosporine, prednisolone and granulocyte colony-stimulating factor for severe aplastic anemia: An update of the GITMO/EBMT study on 100 patients. Blood 2000; 95 (6): 1931-1934

5. Scheinberg P, Nunez O, Wu C, Young NS: Treatment of severe aplastic anaemia with combined immunosuppression: anti-thymocyte globulin, cyclosporin and mycophenolate mofetil. Br J Haematol 2006; 133 (6): 606-611

6. Tisdale JF, Maciejewski JP, Nuñez O, Rosenfeld SJ, Young NS: Late complication following treatment for severe apalstic anemia with high-dose cyclophosphamide: Follow-up of a randomized trial. Blood 2002; 100: 4668-4670

7. Pongtanakul B, Das PK, Charpentier K, Dror Y: Outcome of children with aplastic anemia treated with immunosuppressive therapy. Pediatr Blood Cancer 2008; 50 (1): 52-57

8. Özsoylu Ş: High-dose intravenous methylprednisolone (HIVMP) for acquired aplastic anemia. Eur J Haematol 1988; 41 (5): 508

9. March JC: Treatment of acquired aplastic anemia. Haematologica 2007; 92 (1): 2-5

10. Führer M, Rampf U, Baumann I, Faldum A, Niemeyer C, Janka-Schaub G, Friedrich W, Ebell W, Borkhardt A, Bender-Goetze C: Immunosuppressive therapy for aplastic anemia in children: A more severe disease predicts better survival. Blood 2005; 106 (6): 2102-2104
11. Young NS, Calado RT, Scheinberg P: Current concepts in the pathophysiology and treatment of aplastic anemia. Blood 2006; 108 (8): 2509-2519

12. Huang IA, Jaing TH, Yang CP, Hung IJ, Tsay PK, Luo CC, Sun CF: Single-Center Experience: Immunosuppressive therapy as frontline treatment for 33 children with acquired severe aplastic anemia. Pediatr Hematol Oncol 2009; 26:487-495

13. Kurre P, Johnson FL, Deeg HJ: Diagnosis and treatment of children with aplastic anemia. Pediatr Blood Cancer 2005; 45: $770-780$

14. Rosenfeld S, Follmann D, Nunez O, Young NS: Antithymocyte globulin and cyclosporine for severe aplastic anemia: Association between hematologic response and long term outcome. JAMA 2003; 289: 1130-1135

15. Zheng Y, Liu Y, Chu Y: Immunosuppressive therapy for acquired severe aplastic anemia (SAA): A prospective comparison of four different regimens. Exp Hematol 2006; 34 (7): 826-831

16. Locasciulli A, Bruno B, Rambaldi A, Saracco P, Dufour C, Finelli C, Sica S, Varotto S, Arcese W, Locatelli F, Soligo D, Bacigalupo A: Treatment of severe aplastic anemia with antilymphocyte globulin, cyclosporine and two different granulocyte colony-stimulating factor regimens: A GITMO prospective randomized study. Haematologica 2004; 89 (9): 1054-1061

17. Kojima S, Matsuyama T, Kato S, Kigasawa H, Kobayashi R, Kikuta A, Sakamaki H, Ikuta K, Tsuchida M, Hoshi Y, Morishima Y, Kodera Y: Outcome of 154 patients with severe aplastic anemia who received transplants from unrelated donors: The Japan Marrow Donor Program. Blood 2002; 100 (3): 799-803

18. Beekman R, Touw IP: G-CSF and its receptor in myeloid malignancy. Blood 2010; 115 (25): 5131-5136 